\title{
PEMBELAJARAN IPA DENGAN PENDEKATAN KONTEKSTUAL MELALUI METODE EKSPERIMEN DAN POE DITINJAU DARI KEMAMPUAN MENGGUNAKAN ALAT UKUR DAN KEMAMPUAN VERBAL SISWA
}

\author{
Aris Nurkholis ${ }^{1}$, Widha Sunarno ${ }^{2}$, Suparmi ${ }^{3}$ \\ ${ }^{1}$ Mahasiswa Program Studi Pendidikan Sains, Program Pascasarjana, Universitas Sebelas Maret \\ Surakarta, 57126, Indonesia \\ arisnurkholis@yahoo.com \\ ${ }^{2}$ Program Studi Pendidikan Sains, Program Pascasarjana Universitas Sebelas Maret, Surakarta \\ Surakarta, 57126, Indonesia \\ widhasunarno@gmail.com \\ ${ }^{3}$ Program Studi Pendidikan Sains, Program Pascasarjana Universitas Sebelas Maret, Surakarta \\ Surakarta, 57126, Indonesia \\ suparmiuns@gmail.com
}

\begin{abstract}
ABSTRAK
Tujuan penelitian ini adalah untuk mengetahui pengaruh penggunaan pendekatan kontekstual dengan menggunakan metode pembelajaran POE dan eksperimen, kemampuan menggunakan alat ukur, kemampuan verbal dan interaksinya terhadap prestasi belajar. Penelitian ini menggunakan metode kuasi eksperimental (experimental quation) dengan desain faktorial $2 \times 2 \times 2$. Sampel penelitian ditentukan dengan teknik cluster random sampling sebanyak dua kelas. Teknik pengumpulan data menggunakan metode tes untuk mendapatkan data prestasi belajar kognitif dan kemampuan menggunakan alat ukur, sedangkan metode angket untuk mendapatkan informasi prestasi belajar afektif. Dari hasil penelitian dapat disimpulkan bahwa: (1) terdapat pengaruh penggunaan metode pembelajaran eksperimen dan POE terhadap prestasi kognitif dan afektif; (2) tidak ada pengaruh kemampuan menggunakan alat ukur terhadap prestasi kognitif dan afektif; (3) terdapat pengaruh kemampuan verbal terhadap prestasi kognitif dan afektif; (4) tidak ada interaksi antara metode pembelajaran dengan kemampuan menggunakan alat ukur terhadap prestasi kognitif dan afektif; (5) tidak ada interaksi antara metode pembelajaran dengan kemampuan verbal terhadap prestasi kognitif dan afektif; (6) tidak ada interaksi antara kemampuan menggunakan alat ukur dengan kemampuan verbal terhadap prestasi kognitif dan afektif; (7) tidak ada interaksi antara metode pembelajaran dengan kemampuan menggunakan alat ukur dan kemampuan verbal terhadap prestasi kognitif dan afektif.
\end{abstract}

Kata kunci: pembelajaran kontekstual, eksperimen, POE, kemampuan menggunakan alat ukur, kemampuan verbal. 


\section{Pendahuluan}

Pendidikan nasional memiliki tujuan yang termaktub dalam Undang Undang nomor 20 Tahun 2003 tentang Sistem Pendidikan Nasional yaitu "berkembangnya potensi peserta didik agar menjadi manusia yang beriman dan bertakwa kepada Tuhan Yang Maha Esa, berakhlak mulia, sehat, berilmu, cakap, kreatif, mandiri, dan menjadi warga negara yang demokratis serta bertanggung jawab". Pencapaian tujuan pendidikan tersebut tidak dapat dicapai dengan proses yang mudah dan cepat tetapi diperlukan sarana yang tepat serta waktu yang cukup panjang.

Tujuan pendidikan tersebut akan sulit tercapai apabila orientasi pendidikan mempunyai kecenderungan memperlakukan siswa sebagai obyek pembelajaran, guru berfungsi sebagai pemegang otoritas tertinggi keilmuan dan indoktrinator, materi bersifat subject-oriented, tidak kontekstual dan manajemen bersifat sentralistis. Pendidikan yang demikian menyebabkan siswa tidak diperlakukan sebagai makhluk yang aktif, tidak terlibat aktif dalam menemukan konsep-konsep fisikadan tidak mengkontekstualkan dengan fakta-fakta fisika yang terjadi di lapangan sehingga siswa tidak dpat mencapai tujuan pembelajaran sains yang diharapkan (Zamroni dalam Sutarto Hadi, 2003:1). Dilihat dari kegiatan siswa selama berlangsungnya pembelajaran, Stahl dalam Supinah (2008:1) mengungkapkan bahwa pada pembelajaran konvensional atau tradisional siswa cenderung bekerja untuk dirinya sendiri, mata ke papan tulis dan penuh perhatian, mendengarkan guru dengan seksama, dan belajar hanya dari guru atau bahan ajar, bekerja sendiri, serta hanya guru yang membuat keputusan dan siswa pasif. Hal ini mengidentifikasikan bahwa dalam pembelajaran di sekolah guru masih menggunakan cara-cara tradisional atau konvensional.

Dari beberapa faktor-faktor di atas, menjadi salah satu faktor yang menyebabkan kualitas pendidikan di Indonesia masih rendah khususnya pendidikan sains. Hal ini terungkap dalam hasil studi The Third International Mathematics and Science Study (TIMSS) tahun 2007 bidang science, Indonesia menduduki peringkat 35 dari 48 negara dengan nilai 427 , padahal skor rata-rata internasional adalah 500
(Williams, T et al. 2009: 2). Secara ringkas dapat diartikan bahwa sulitnya pembelajaran IPA ditandai dengan kurangnya proses, produk dan sikap penguasaan pengetahuan, konsep yang abstrak kurang mendapatkan minat bagi siswa dan kurangnya menerapkan teori dapat bermanfaat dalam kehidupan sehari-hari.

Sebagai upaya meningkatkan kualitas pendidikan agar sesuai dengan tujuan pendidikan yang telah ditetapkan, pemerintah Indonesia telah melakukan pembaharuan melalui pengembangan kurikulum, mulai dari kurikulum lama yang cenderung content based menjadi kurikulum yang berbasis kompetensi (competency based). Kemudian diperbaharui dengan kurikulum tingkat satuan pendidikan (KTSP).

Dalam pedoman penyusunan kurikulum tingkat satuan pendidikan (Mulyasa, 2006: 151-153), terdapat beberapa ciri penting dalam pengembangan kurikulum tingkat satuan pendidikan (KTSP) yaitu pertama; berpusat pada potensi, perkembangan, kebutuhan, dan kepentingan peserta didik dan lingkungannya. Kedua, beragam dan terpadu. Ketiga, tanggap terhadap perkembangan ilmu pengetahuan, teknologi, dan seni. Keempat, relevan dengan kebutuhan kehidupan masa kini dan masa datang. Kelima, menyeluruh dan berkesinambungan. Keenam, belajar sepanjang hayat. Ketujuh, seimbang antara kepentingan nasional dan daerah.

Secara umum pembelajaran Fisika di SMP Muhammadiyah 4 Yogyakarta berpedoman pada kurikulum KTSP, namun realitasnya pembelajaran berlangsung dengan berorientasi pada target pencapaian KKM yaitu 7,0, oleh sebab itu guru memilih pembelajaran dengan mempercepat materi yaitu dengan metode ceramah dan membahas soal-soal ketika proses kegiatan belajar mengajar berlangsung. Keterlibatan siswa dalam belajar Fisika, lebih pada ranah konsep menghafal rumus-rumus kemudian diaplikasikan dengan penerapan soalsoal latihan. Keberhasilan proses pembelajaran tidak semata-mata dipengaruhi oleh pelaksanaan pembelajaran di kelas.

Berdasarkan paparan di atas, maka guru perlu menemukan pendekatan dan cara/metode terbaik dalam menyampaikan berbagai konsep materi yang diajarkan di dalam mata pelajaran sains, selain itu guru juga harus memperhatikan kondisi siswa, sifat materi bahan ajar, dan 
fasilitas-media yang tersedia (Isjoni, 2007: 8). Ada berbagai macam pendekatan yang dapat digunakan antara lain pendekatan konsep, pendekatan kontruktivistik, pendekatan kooperatif atau Cooperative Learning, pendekatan kontekstual atau Contextual Teaching and Learning (CTL), pendekatan pembelajaran berbasis masalah atau Problem Based Learning (PBL) dan sebagainya (Trianto, 2010: 26). Meskipun telah banyak pendekatan pembelajaran Fisika yang berorientasi pada proses dan sikap, namun pendekatan ini belum banyak diterapkan oleh para guru untuk membelajarkan IPA, khususnya Fisika.

Fungsi dan tujuan pembelajaran IPA yaitu mampu mengembangkan keterampilan, sikap, dan nilai ilmiah, dan menguasai konsep sains untuk bekal hidup di masyarakat dan melanjutkan pendidikan ke jenjang yang lebih tinggi (Depdiknas, 2004: 2). Salah satu indikator ketercapaiannya terlihat pada indikator kedua yaitu siswa mampu mengembangkan keterampilan, sikap, dan nilai ilmiah. Tujuan tersebut tersirat bahwa siswa dituntut tidak hanya mampu mengerjakan soalsoal akan tetapi juga harus memiliki karakter sains yaitu metode ilmiah karena Fisika merupakan ilmu yang lahir dan berkembang lewat langkah-langkah observasi, perumusan masalah, penyusunan hipotesis, pengujian hipotesis melalui eksperimen, penarikan kesimpulan, serta penemuan teori dan konsep.

Konsep getaran dan gelombang sering dijumpai dalam kehidupan sehari-hari, namun dalam kenyataannya konsep getaran dan gelombang masih sulit dipahami oleh siswa karena penyampaian materi yang kurang menarik, kurang kontekstual, membosankan dan pendekatan pembelajaran yang cenderung matematis saja. Sehingga dapat diartikan bahwa ketika siswa belajar materi getaran dan gelombang membutuhkan pengalaman langsung peristiwa-peristiwa getaran dan gelombang dalam kehidupan sehari-hari.

Berdasarkan tujuan pembelajaran IPA dan karakteristik materi maka pemahaman konsep yang dimiliki siswa dibangun dari proses asimilasi sampai ekuilibrasi memerlukan proses pembangunan pengetahuan secara mandiri dan kontekstual. Menurut Riyanto (2010:59) "pendekatan pembelajaran kontekstual adalah konsep belajar yang membantu guru mengaitkan antara materi yang diajarkan dengan situasi dunia nyata siswa dan mendorong antara pengetahuan yang dimilikinya dengan penerapannya dalam kehidupan mereka sehari-hari sebagai anggota keluarga dan masyarakat".

Metode yang memungkinkan membangun pengetahuan siswa secara mandiri dan kontekstual serta meningkatkan keaktifan siswa adalah metode POE dan eksperimen. Menurut Paul Suparno (2007:102) "metode pembelajaran POE (prediction, observation, and explanation) adalah suatu metode pembelajaran yang menggunakan tiga langkah utama dari metode ilmiah yaitu pertama prediction atau membuat prediksi, membuat dugaan terhadap suatu peristiwa Fisika; kedua observation yaitu melakukan penelitian, pengamatan apa yang terjadi; ketiga explanation yaitu memberi penjelasan tentang kesesuaian antara dugaan dengan yang sungguh terjadi."

Menurut Winataputra (2001: 219) "metode eksperimen adalah suatu cara penyajian materi pelajaran dimana siswa secara aktif mengalami dan membuktikan sendiri tentang apa yang dipelajarinya". Melalui metode ini siswa secara total dilibatkan dalam melakukan sendiri, mengikuti proses, mengamati suatu objek, menganalisis, membuktikan dan menarik kesimpulan sendiri tentang suatu objek, keadaan atau proses sesuatu. Jadi metode ini lebih untuk mengecek supaya siswa makin yakin dan jelas akan teorinya. Pemilihan metode yang tepat harus disesuaikan dengan karakteristik materi maupun tingkat kognitif siswa hal ini diharapkan akan mampu menunjang prestasi belajar.

Prestasi belajar siswa dalam proses pembelajaran dipengaruhi oleh beberapa faktor, menurut Slameto (2010: 54) mengemukakan bahwa "faktor-faktor yang mempengaruhi belajar banyak jenisnya tetapi dapat digolongkan menjadi dua golongan saja. Yaitu faktor internal dan eksternal". Jadi dapat diartikan bahwa faktor internal dan faktor eksternal tersebut saling mempengaruhi dalam proses belajar individu sehingga menentukan kualitas hasil belajar.

Faktor internal yang mempengaruhi prestasi belajar siswa antara lain intelegensi, kemampuan menggunakan alat ukur, kemampuan memori, kemampuan verbal, minat, bakat, motivasi, kesehatan jasmani, kesehatan rohani, dan lain-lain. Sedangkan 
faktor eksternal yang mempengaruhi prestasi belajar siswa antara lain guru, bahan pelajaran, metode mengajar, lingkungan, sarana dan prasarana, interaksi yang terjadi antar siswa ataupun interaksi antara siswa dengan guru dan lain-lain.

Pemilihan pendekatan dan metode pembelajaran adalah bagaian faktor ekternal yang mempengaruhi prestasi belajar siswa, oleh sebab itu perlu diselaraskan dengan faktor internal. Diantara beberapa faktor internal yang mendukung dalam pendekatan kontekstual dengan metode POE dan eksperimen yaitu kemampuan menggunakan alat ukur dan kemampuan verbal siswa.

Menurut Winkel (1983:134) "setiap proses belajar mengajar mempunyai titik tolak sendiri atau berpangkal pada kemampuan siswa tertentu (tingkah laku awal) untuk dikembangkan menjadi kemampuan baru, sesuai dengan tujuan instruksional (tingkah laku final). Oleh karena itu, keadaan siswa pada awal proses belajar mengajar tertentu (tingkah laku awal) mempunyai relevansi terhadap penentuan, perumusan, dan pencapaian tujuan instruksional (tingkah laku final)."

Berdasarkan pendapat Winkel tersebut, jika kemampuan awal siswa tinggi maka dalam proses belajar berikutnya siswa tersebut tidak akan mengalami kesulitan. Siswa hanya mengembangkan kemampuan awal tersebut menjadi kemampuan baru sesuai dengan tujuan yang ingin dicapai. Sebaliknya apabila kemampuan awal siswa rendah maka siswa tersebut akan mengalami kesulitan untuk mencapai tujuan yang diinginkan sehingga perlu waktu yang lebih lama. Kemampuan awal dalam penelitian ini adalah kemampuan siswa dalam menggunakan alat ukur.

Kemampuan verbal menurut Winkel (1983: 99), "kemampuan yang dimiliki seseorang dalam menuangkan pengetahuan dan pengalaman yang dimiliki dalam bentuk bahasa yang memadai, sehingga dapat dikomunikasikan kepada orang lain". Kemampuan verbal akan memperlancar penyampaian komunikasi dalam penerapan pembelajaran kontekstual melalui metode POE.

Berdasarkan uraian di atas, maka perlu dilaksanakan penelitian pembelajaran Fisika dengan pendekatan kontekstual melalui metode POE dan eksperimen ditinjau dari kemampuan menggunakan alat ukur dan kemampuan verbal siswa. Adapun tujuan dalam penelitian ini adalah untuk mengetahui: 1) pengaruh pendekatan pembelajaran kontekstual dengan metode POE dan eksperimen terhadap prestasi belajar siswa; 2) pengaruh kemampuan menggunakan alat ukur tinggi dan rendah terhadap prestasi belajar siswa; 3) pengaruh kemampuan verbal tinggi dan rendah terhadap prestasi belajar siswa; 4) interaksi antara metode pembelajaran dengan kemampuan menggunakan alat ukur terhadap prestasi belajar; 5) interaksi antara metode pembelajaran dengan kemampuan verbal terhadap prestasi belajar siswa; 6) interaksi antara kemampuan menggunakan alat ukur dengan kemampuan verbal terhadap prestasi belajar siswa; 7) interaksi antara metode pembelajaran, kemampuan menggunakan alat ukur, dan kemampuan verbal terhadap prestasi belajar siswa

\section{Metode Penelitian}

Penelitian ini dilaksanakan di SMP Muhammadiyah 4 Yogyakarta. Penelitian dilaksanakan dari bulan Februari - Maret 2012. Penelitian ini menggunakan metode kuasi eksperimen. Kelompok eksperimen I diajar dengan pendekatan kontekstual dengan metode POE dan kelompok eksperimen II diajar dengan pendekatan kontekstual dengan metode eksperimen.

Rancangan penelitian ini menggunakan desain faktorial dengan rancangan penelitian Anava tiga jalan $2 \times 2 \times 2$. Variabel bebas meliputi pendekatan kontekstual menggunakan metode POE dan eksperimen, variabel terikat adalah prestasi belajar siswa dan variabel moderator kemampuan menggunakan alat ukur dan kemampuan verbal siswa.

Pengumpulan data dilakukan dengan menggunakan tes untuk mengukur prestasi belajar kognitif, kemampuan menggunakan alat ukur, dan kemampun verbal siswa. Dan data prestasi afektif melalui angket. Data tes kemampuan menggunakan alat ukur dan kemampuan verbal diperoleh sebelum perlakuan, sedangkan data prestasi belajar diperoleh setelah sampel diberikan perlakuan.

Data yang diperoleh selanjutnya dianalisis secara deskriptif dan statistik dilanjutkan dengan uji Scheffe. Uji statistik anava dilakukan pada taraf signifikansi 5\%. Sebelum dilakukan analisis statistik dilakukan uji prasyarat, yaitu 
uji homogenitas dan uji normalitas terhadap data yang diperoleh.

\section{Hasil Penelitian dan Pembahasan}

Data penelitian ini diperoleh melalui tes kemampuan menggunakan alat ukur, tes kemampuan verbal, dan tes prestasi belajar pada aspek kognitif. Sedangkan data prestasi belajar pada aspek afektif diperoleh menggunakan angket.

Deskripsi kategori kemampuan menggunakan alat ukur dan kemampuan verbal dikategorikan tinggi jika skor tes $\geq$ skor ratarata total tes dan rendah jika skor tes < skor rata-rata total tes. Distribusi frekuensi kemampuan menggunakan alat ukur dan kemampuan verbal dapat dilihat pada Tabel 1 dan Tabel 2, sedangkan data prestasi belajar siswa berdasarkan pendekatan pembelajaran kontekstual dengan metode POE dan eksperimen disajikan Tabel 3.

Tabel 1 Distribusi Frekuensi Kemampuan Menggunakan Alat Ukur

\begin{tabular}{lcccc}
\hline $\begin{array}{c}\text { Kemampuan } \\
\text { Menggunakan Alat }\end{array}$ Ukur & \multicolumn{2}{c}{ Metode POE } & \multicolumn{2}{c}{$\begin{array}{c}\text { Metode } \\
\text { Eksperimen }\end{array}$} \\
\cline { 2 - 5 } & Frek. & $\%$ & Frek. & $\%$ \\
\hline Tinggi & 19 & $56 \%$ & 19 & $58 \%$ \\
Rendah & 15 & $44 \%$ & 14 & $42 \%$ \\
Jumlah & 34 & $100 \%$ & 33 & $100 \%$ \\
\hline
\end{tabular}

Tabel 1 menunjukkan bahwa frekuensi kemampuan menggunakan alat ukur tinggi lebih dominan dibandingkan dengan kemampuan menggunakan alat ukur rendah.

Tabel 2 Distribusi Data Kemampuan Verbal Tinggi dan Rendah

\begin{tabular}{lcccc}
\hline \multirow{2}{*}{$\begin{array}{c}\text { Kemampuan } \\
\text { verbal }\end{array}$} & \multicolumn{2}{c}{ Metode POE } & \multicolumn{2}{c}{$\begin{array}{c}\text { Metode } \\
\text { Eksperimen }\end{array}$} \\
\cline { 2 - 5 } & Frek. & $\%$ & Frek. & $\%$ \\
\hline Tinggi & 14 & $41 \%$ & 17 & $52 \%$ \\
Rendah & 20 & $59 \%$ & 16 & $48 \%$ \\
Jumlah & 34 & $100 \%$ & 33 & $100 \%$ \\
\hline
\end{tabular}

Tabel 2 menunjukan bahwa frekuensi kemampuan verbal tinggi lebih rendah dibandingkan dengan kemampuan verbal rendah.

Tabel 3 Rata-rata Prestasi Belajar Siswa Berdasarkan Metode Pembelajaran

\begin{tabular}{lccc}
\hline Kelas & Jumlah & Kognitif & Afektif \\
\hline Metode POE & 34 & 72,94 & 162,88 \\
Metode & 33 & 68,18 & 157,33 \\
Eksperimen & & & \\
\hline
\end{tabular}

Tabel 3 menunjukan bahwa nilai rata-rata prestasi belajar kognitif dan afektif pembelajaran dengan menggunakan pendekatan kontekstual menggunakan metode POE lebih baik daripada menggunakan metode eksperimen.

Data penelitian dianalisis statistik menggunakan anava $2 \times 2 \times 2$ dan dilanjutkan dengan uji Scheffe. Rangkuman hasil uji statistik disajikan pada Tabel 4 dan Tabel 5.

Tabel 4 Ringkasan Anava Tiga Jalan Prestasi Kognitif

\begin{tabular}{|c|c|c|c|}
\hline No. & Sumber Variansi & p-value & Keputusan Uji \\
\hline 1. & Metode & 0,002 & $\mathrm{H}_{01}$ ditolak \\
\hline 2. & $\begin{array}{l}\text { Kemampuan } \\
\text { Menggunakan alat } \\
\text { ukur }\end{array}$ & 0,055 & $\begin{array}{c}\mathrm{H}_{02} \text { tidak } \\
\text { ditolak }\end{array}$ \\
\hline 3. & Kemampuan Verbal & 0,000 & $\mathrm{H}_{03}$ ditolak \\
\hline 4. & $\begin{array}{l}\text { Metode * Kem. } \\
\text { Menggunakan alat } \\
\text { ukur }\end{array}$ & 0,757 & $\begin{array}{l}\mathrm{H}_{012} \text { tidak } \\
\text { ditolak }\end{array}$ \\
\hline 5. & $\begin{array}{l}\text { Metode * Kem. } \\
\text { Verbal }\end{array}$ & 0,630 & $\begin{array}{l}\mathrm{H}_{013} \text { tidak } \\
\text { ditolak }\end{array}$ \\
\hline 6. & $\begin{array}{l}\text { K. Menggunakan alat } \\
\text { ukur* K. Verbal }\end{array}$ & 0,601 & $\begin{array}{c}\mathrm{H}_{023} \text { tidak } \\
\text { ditolak }\end{array}$ \\
\hline 7. & $\begin{array}{l}\text { Metode * Kem. } \\
\text { Menggunakan alat } \\
\text { ukur* K. Verbal }\end{array}$ & 0,897 & $\begin{array}{c}\mathrm{H}_{0123} \text { tidak } \\
\text { ditolak }\end{array}$ \\
\hline
\end{tabular}

Tabel 5 Ringkasan Anava Tiga Jalan Prestasi Afektif

\begin{tabular}{|c|c|c|c|}
\hline No. & Sumber Variansi & $p$-value & Keputusan Uji \\
\hline 1 & Metode & 0,003 & $\mathrm{H}_{01}$ ditolak \\
\hline 2 & $\begin{array}{l}\text { Kemampuan } \\
\text { Menggunakan alat } \\
\text { ukur }\end{array}$ & 0,822 & $\mathrm{H}_{02}$ tidak ditolak \\
\hline 3 & Kemampuan Verbal & 0,000 & $\mathrm{H}_{03}$ ditolak \\
\hline 4 & $\begin{array}{l}\text { Metode * Kem. } \\
\text { Menggunakan alat } \\
\text { ukur }\end{array}$ & 0,741 & $\mathrm{H}_{012}$ tidak ditolak \\
\hline 5 & $\begin{array}{l}\text { Metode } * \text { Kem. } \\
\text { Verbal }\end{array}$ & 0,637 & $\mathrm{H}_{013}$ tidak ditolak \\
\hline 6 & $\begin{array}{l}\text { K. Menggunakan } \\
\text { alat ukur* } \\
\text { K. Verbal }\end{array}$ & 0,966 & $\mathrm{H}_{023}$ tidak ditolak \\
\hline 7 & $\begin{array}{l}\text { Metode * Kem. } \\
\text { Menggunakan alat } \\
\text { ukur* K. Verbal }\end{array}$ & 0,444 & $\begin{array}{l}\mathrm{H}_{0123} \text { tidak } \\
\text { ditolak }\end{array}$ \\
\hline
\end{tabular}

a. Pengaruh pembelajaran kontekstual dengan menggunakan metode POE dan eksperimen terhadap prestasi

Pembelajaran kontekstual merupakan konsep belajar yang membantu guru mengaitkan antara materi yang disampaikan dengan situasi dunia nyata siswa dan mendorong siswa membuat hubungan antara pengetahuan yang dimiliki dengan penerapannya dalam kehidupan sehari-hari (Sagala, 2011:87). Pendekatan pembelajaran 
kontekstual dalam penelitian ini menggunakan metode POE dan eksperimen. Pada pelaksanaan kedua metode pembelajaran ini pada dasarnya sama yaitu sama-sama mendorong siswa untuk menemukan pengetahuan secara mandiri. Dari data hasil pengamatan, kelas dengan metode POE lebih baik dibandingkan dengan kelas dengan metode eksperimen. Hal ini disebabkan karena metode POE yang digunakan dengan inquiry. Maksudnya, siswa aktif dalam menemukan pengetahuan secara mandiri. Dimulai dari kegiatan menduga, dalam hal ini siswa aktif membuat dugaan terhadap suatu persoalan Fisika yang disajikan oleh guru. Kemudian melakukan observasi, dalam hal ini siswa aktif mengamati secara langsung persoalan Fisika, dengan ini siswa akan menguji dugaan yang dibuat sesuai atau tidak dengan kenyataan. Dan yang terakhir, siswa memberikan penjelasan tentang hasil yang diamatinya dengan yang diduga. Apabila dugaan siswa ternyata terjadi dalam pengamatannya, maka siswa akan semakin yakin akan konsepnya. Hal ini sejalan dengan pernyataan yang disampaikan Paul Suparno (2007:102) bahwa "metode POE menuntut siswa untuk mampu mengkonstruksi konsep pengetahuannya secara mandiri, siswa aktif berfikir tentang suatu persoalan Fisika dan siswa aktif melakukan pengamatan serta mencari penjelasannya". Sehingga pengetahuan yang didapat dari proses tersebut akan semakin kuat tertanam diri siswa dan lebih bertahan lama atau sulit untuk dilupakan. Akibatnya, prestasi belajar siswa menunjukkan hasil yang memuaskan. Hakan Ozdemir (2011) dalam Western Anatolia Joernal Education Science yang menyebutkan bahwa penggunaan strategi POE berpengaruh secara signifikan terjadap prestasi belajar siswa. Lebih lanjut Hakan Ozdemir menyebutkan bahwa penggunaan strategi POE membantu siswa untuk mendapatkan pemahaman yang lebih baik tentang konsep-konsep ilmiah. Selain itu David F. Treagust (2007) dalam hasil penelitiannya juga menyebutkan bahwa metode POE cukup efektif untuk meningkatkan pembelajaran bermakna di kelas.

Sedangkan pada penggunaan metode eksperimen dalam penelitian ini hasil tidak lebih baik daripada penggunaan metode POE. Pada dasarnya pelaksanaan kedua metode tersebut sebenarnya sama yaitu sama-sama mendorong siswa untuk menemukan pengetahuan secara mandiri. Namun dalam pelaksanaannya metode eksperimen tidak sepenuhnya sesuai dengan prinsip dan kaedah metode pembelajaran eksperimen. Diantaranya adalah tidak dengan inquiry dan masih bersifat konvensional. Maksudnya, siswa hanya diminta untuk melakukan kegiatan sesuai dengan yang terdapat pada lembar kerja siswa (LKS) sehingga siswa tidak dituntut untuk kritis. Akibatnya, prestasi belajar siswa belum menunjukkan hasil yang memuaskan. Dengan demikian, pendekatan pembelajaran kontekstual akan menghasilkan prestasi belajar yang lebih baik jika diajarkan dengan metode POE daripada diajarkan dengan menggunakan metode eksperimen pada pokok bahasan Getaran dan gelombang.

\section{a. Hipotesis Kedua}

Berdasarkan hasil keputusan uji maka Ho diterima pada prestasi kognitif dan afektif. Hal ini dapat disimpulkan bahwa tidak ada pengaruh kemampuan menggunakan alat ukur terhadap prestasi belajar kognitif dan afektif.

Kemampuan menggunakan alat ukur tidak berpengaruh secara signifikan terhadap prestasi belajar, hal ini berbeda dengan hipotesis yang dirumuskan yang menyatakan bahwa kemampuan menggunakan alat ukur memiliki pengaruh yang signifikan terhadap prestasi belajar siswa. Hipotesis tersebut dibangun atas landasan teori Ausebel yang menyebutkan proses pembelajaran akan bermakna dan informasi yang didapat oleh siswa akan bertahan lama jika ada kaitannya antara konsepsi awal dengan konsep yang sedang dipelajari siswa (Dahar, 1989:103). Konsepsi awal dalam hal ini adalah kemampuan awal siswa dalam menggunakan alat ukur. Namun di satu sisi lain terdapat penelitian yang dilakukan oleh Daimul Khasanah (2010) yang dalam salah satu kesimpulannya menyatakan bahwa "kemampuan menggunakan alat ukur tidak berpengaruh signifikan terhadap prestasi belajar siswa". Sehingga hasil penelitian ini sejalan dengan hasil penelitian yang dilakukan oleh Daimul khasanah yang menyatakan kemampuan menggunakan alat ukur tidak berpengaruh signifikan terhadap prestasi belajar siswa.

Tidak adanya pengaruh kemampuan menggunakan alat ukur tinggi dan kemampuan 
menggunakan alat ukur rendah terhadap prestasi kognitif siswa diantaranya: Pertama; disebabkan karena instrumen pengambilan data untuk memperoleh informasi tentang kemampuan menggunakan alat ukur siswa hanya diperoleh dari tes tertulis pilihan ganda saja. Sehingga data kemampuan menggunakan alat ukur yang diperoleh kurang akurat dan kurang dapat dipercaya. Karena tes tertulis pilihan ganda terdapat kelemahan jika digunakan untuk mengukur kemampuan/ keterampilan/ skill yang dimiliki siswa. Maka daripada itu dibutuhkan pula sebuah instrumen atau tes lain yang dapat digunakan untuk mengukur penampilan atau kinerja yang telah dikuasai siswa. Instrumen tersebut bisa langsung tes praktek ataupun tes tertulis namun tes tertulis yang menjadi sasarannya adalah kemampuan peserta didik dalam menampilkan karya. Dengan demikian, untuk memperoleh informasi tentang kemampuan menggunakan alat ukur yang lebih valid dari para siswa, sebaiknya selain adanya tes tertulis perlu juga adanya tes keterampilan menggunakan alat ukur dan observasi secara langsung pada siswa yang bersangkutan. Kedua; disebabkan karena data kemampuan menggunakan alat ukur pada penelitian ini hanya dikategorikan menjadi dua kategori yaitu kategori tinggi dan kategori rendah. Dalam penelitian ini peneliti tidak melibatkan kategori sedang. Hal ini sedikit memberikan pengaruh terhadap hasil penelitian, karena semakin ketat pengklasifikasian data maka hasil yang diperoleh pun akan semakin valid. Berbeda dengan sebaliknya apabila pengklasikasian terlalu sedikit maka peluang untuk data yang diperoleh kurang valid semakin besar. Ketiga; disebabkan karena dalam melakukan percobaan dilakukan secara kelompok, dan adanya keterbatasan waktu dalam melakukan percobaan sehingga tidak semua siswa terlibat dalam melakukan percobaan. Sehingga siswa yang memiliki kemampuan menggunakan alat ukur tinggi belum tentu ikut terlibat menggunakan alat ukur untuk melakukan percobaan. Hal inilah yang menyebabkan antara siswa yang memiliki kemampuan menggunakan alat ukur tinggi dan rendah tidak ada pengaruh yang signifikan.

\section{b. Hipotesis Ketiga}

Berdasarkan hasil keputusan uji maka Ho ditolak pada prestasi kognitif dan afektif. Hal ini dapat disimpulkan bahwa terdapat pengaruh kemampuan verbal terhadap prestasi belajar kognitif dan prestasi belajar afektif.

Kemampuan verbal berpengaruh secara signifikan terhadap prestasi belajar kognitif hal ini sesuai dengan Hawkins, et al. (2007) yang menyatakan kemampuan verbal sangat cocok untuk diinduksikan dalam proses belajar dikelas. Hal ini juga sesuai dengan Gagne cit. Winkel (1983: 322) menyatakan bahwa "dalam mengelola informasi baru dan mengkaitkannya dengan informasi lama selama informasi tersebut berada dalam ingatan jangka pendek, siswa harus mengadakan organisasi mental yang diekspresikan dalam bentuk verbal (perumusan bahasa yang memadai)". Dalam membangun konsep pengetahuan mengenai Getaran dan gelombang hal ini sangat membutuhkan siswa secara aktif untuk berani bertanya, menjawab, dan perpendapat sehingga akan terjadi proses asimilasi dan akomodasi pengetahuan yang diperoleh. Sehingga siswa yang memiliki kemampuan verbal tinggi akan mendapatkan prestasi yang lebih baik dibandingkan siswa yang memiliki kemampuan verbal rendah.

Kemampuan verbal tinggi dan rendah terhadap prestasi belajar afektif memberikan pengaruh yang signifikan. Hal ini dikarenakan pendekatan kontekstual memiliki kecenderungan siswa untuk berani mengemukakan pendapat, restrukturisasi ide dengan menanggapi ide yang berbeda sehingga siswa yang memiliki kemampuan verbal tinggi mereka dengan percaya diri untuk mengemukakan pendapatnya dan lebih aktif di kelas daripada siswa yang memiliki kemampuan verbal rendah.

\section{c. Hipotesis Keempat}

Berdasarkan hasil keputusan uji maka Ho diterima pada prestasi kognitif dan prestasi afektif. Hal ini dapat disimpulkan bahwa tidak terdapat interaksi pembelajaran kontekstual menggunakan metode POE dan eksperimen dengan kemampuan menggunakan alat ukur terhadap prestasi kognitif dan afektif.

Kesimpulan ini sejalan dengan hasil penelitian yang dilakukan oleh Daimul Khasanah (2010) tentang pembelajaran Fisika dengan metode eksperimen dan demonstrasi ditinjau dari kemampuan menggunakan alat ukur dan sikap ilmiah siswa. Salah satu 
kesimpulannya menyatakan bahwa tidak ada interaksi antara metode pembelajaran dengan kemampuan menggunakan alat ukur terhadap prestasi belajar.

Hal ini dikarenakan siswa yang mendapat perlakuan metode eksperimen dalam pelaksanaanya hampir seluruh siswa mampu menggunakan alat ukur dengan baik dan benar, karena kemampuan menggunakan alat ukur sudah pernah dipelajari oleh siswa di kelas VII dan juga alat ukur tersebut sudah sering digunakan oleh siswa dalam kehidupan seharihari. Kemampuan menggunakan alat ukur berkaitan menjadi kemampuan dasar siswa dalam melakukan eksperimen, maka siswa yang memiliki kemampuan menggunakan alat ukur kategori tinggi memiliki nilai rata-rata prestasi kognitif lebih tinggi $(69,84)$ dibandingkan dengan siswa yang memiliki kemampuan menggunakan alat ukur kategori rendah $(67,71)$.

Sedangkan untuk siswa yang mendapat perlakuan dengan metode POE lebih mengedepankan siswa untuk aktif berinteraksi, aktif menyampaikan pendapat dan gagasannya berupa dugaan-dugaan sementara. hal ini berdampak terhadap kurangnya pemerataan keaktifan siswa dalam proses belajar. Kemampuan menggunakan alat ukur berkaitan dengan kemampuan dasar seorang siswa untuk melakukan eksperimen. Dalam hal ini metode POE kurang mampu memfasilitasi siswa untuk melakukan proses pengukuran dengan menggunakan alat ukur, karena pada kenyataanya hanya sebagian kecil siswa yang mau mencoba untuk melakukan pengukuran menggunakan alat ukur sehingga siswa seharusnya yang memiliki kemampuan menggunakan alat ukur kategori tinggi memiliki nilai rata-rata prestasi kognitif lebih rendah atau minimal sama dibandingkan dengan siswa yang memiliki kemampuan menggunakan alat ukur kategori tinggi. Namun dalam kenyataannya justru terbalik siswa yang memiliki kemampuan menggunakan alat ukur kategori tinggi memiliki nilai rata-rata prestasi kognitif lebih tinggi $(74,15)$ dibandingkan dengan siswa yang memiliki kemampuan menggunakan alat ukur kategori tinggi $(71,33)$.

\section{d. Hipotesis Kelima}

Berdasarkan hasil keputusan uji maka Ho diterima pada prestasi kognitif dan afektif. Hal ini dapat disimpulkan bahwa tidak terdapat interaksi pembelajaran kontekstual menggunakan metode POE dan eksperimen dengan kemampuan verbal terhadap prestasi kognitif dan afektif.

Kesimpulan ini sejalan dengan hasil penelitian yang dilakukan oleh Dimas Candra (2007) yang dalam salah satu kesimpulannya menyatakan bahwa tidak ada interaksi antara metode pembelajaran dengan kemampuan verbal siswa terhadap prestasi belajar. Namun hasil penilitian ini berbeda dengan hipotesis yang disusun sebelumnya yang menyatakan bahwa terdapat interaksi antara metode pembelajaran dengan kemampuan verbal terhadap prestasi belajar siswa.

Hal ini dikarenakan siswa yang mendapat perlakuan metode POE dalam pelaksanaannya hampir seluruh siswa aktif untuk belajar, karena setiap pembelajaran siswa dituntut untuk aktif mengungkapkan ide-ide, gagasan, dan pendapatnya. Karena kemampuan verbal berkaitan dengan ide-ide yang disampaikan dalam kata-kata maka metode POE mampu mengoptimalkan ide-ide atau gagasan pengetahuan diperoleh siswa yang lebih cenderung kebahasa lisan daripada tulisan. Hasilnya siswa yang memiliki kemampuan verbal tinggi memiliki nilai rata-rata prestasi tertinggi dan bahkan siswa yang memiliki kemampuan verbal rendah nilai rata-rata prestasi lebih tinggi jika dibandingkan dengan metode eksperimen dengan kemampuan verbal tinggi ataupun kemampuan verbal rendah.

Untuk siswa yang mendapat perlakuan dengan metode eksperimen lebih mengedepankan keaktifan siswa dalam kelompok, hal ini berdampak terhadap kurangnya pemerataan keaktifan siswa dalam proses belajar. Kemampuan kemampuan verbal berkaitan dengan ide-ide yang disampaikan dalam kata-kata maka metode eksperimen kurang mampu memfasilitasi siswa untuk bisa menyampaikan ide atau gagasannya baik lisan ataupun tulisan, karena pada kenyataanya hanya sebagian siswa yang mampu mengungkapkan pengetahuan-pengetahuan yang sudah didapatkan. Dari pemaparan tersebut dapat diringkas bahwa tidak adanya interaksi antara metode pembelajaran dengan kemampuan verbal terhadap prestasi belajar dikarenakan metode POE mampu memfasilitasi keaktifan sebagian besar siswa sedangkan metode eksperimen hanya mampu memfasilitasi 
sebagian kecil siswa dalam mengoptimalkan kemampuan verbal baik lisan maupun tulisan.

\section{e. Hipotesis Keenam}

Berdasarkan hasil keputusan uji maka Ho diterima pada prestasi kognitif dan afektif. Hal ini dapat disimpulkan bahwa tidak terdapat interaksi kemampuan menggunakan alat ukur dengan kemampuan verbal terhadap prestasi kognitif dan afektif. Hasil kesimpulan ini berbeda dengan hipotesis yang telah dirumuskan sebelumnya yang menyatakan terdapat interaksi antara kemampuan menggunakan alat ukur dengan kemampuan verbal siswa. Kerangka berfikir yang dibangun dalam hipotesis tersebut berdasarkan teori Ausebel yang menyebutkan proses pembelajaran akan bermakna dan informasi yang didapat oleh siswa akan bertahan lama jika ada kaitannya antara konsepsi awal dengan konsep yang sedang dipelajari siswa (Dahar, 1989:103). Konsepsi awal dalam hal ini adalah kemampuan awal siswa dalam menggunakan alat ukur. Selain teori Ausebel dalam hipotesis ini juga diungkapkan teori yang mendukung lainnya yaitu teori Gagne cit. Winkel (1983: 322) menyatakan bahwa "dalam mengelola informasi baru dan mengkaitkannya dengan informasi lama selama informasi tersebut berada dalam ingatan jangka pendek, siswa harus mengadakan organisasi mental yang diekspresikan dalam bentuk verbal (perumusan bahasa yang memadai)". Dalam membangun konsep pengetahuan mengenai Getaran dan gelombang hal ini sangat membutuhkan siswa secara aktif untuk berani bertanya, menjawab, dan perpendapat sehingga akan terjadi proses asimilasi dan akomodasi pengetahuan yang diperoleh. Sehingga berdasarkan teori yang dibangun tersebut maka hipotesis ini menyatakan terdapat interaksi antara kemampuan menggunakan alat ukur dengan kemampuan verbal.

Namun hasil penelitian ini menunjukan hasil bahwa tidak ada interaksi antara kemampuan menggunakan alat ukur dengan kemampuan verbal siswa terhadap prestasi belajar. Tidak adanya interaksi antara kemampuan menggunakan alat ukur dengan kemampuan verbal hal ini dikarenakan siswa yang memiliki kemampuan menggunakan alat ukur tinggi dan kemampuan verbal tinggi lebih dapat mengikuti proses pembelajaran. Karena dalam pembelajaran baik dengan menggunakan metode POE maupun metode eksperimen mereka tidak ada kendala dalam proses pembelajaran. Yang mana kedua metode tersebut mensyaratkan adanya kemampuan menggunakan alat ukur tinggi untuk metode eksperimen dan kemampuan verbal tinggi untuk metode POE. Berbeda sebaliknya dengan siswa yang memiliki kemampuan menggunakan alat ukur tinggi dan kemampuan verbal rendah mereka sedikit terkendala dalam proses pembelajaran ketika metode yang digunakan adalah metode POE, sehingga prestasi kognitif siswa yang memiliki kemampuan menggunakan alat ukur tinggi dan kemampuan verbal rendah lebih rendah dibandingkan dengan siswa yang memiliki kemampuan menggunakan alat ukur tinggi dan kemampuan verbal tinggi.

Selain itu, tidak adanya interaksi antara kemampuan menggunakan alat ukur dengan kemampuan verbal adalah dikarenakan siswa yang memiliki kemampuan menggunakan alat ukur rendah dan kemampuan verbal tinggi lebih dapat mengikuti proses pembelajaran walaupun ada sedikit kendala ketika pembelajaran menggunakan metode eksperimen. Berbeda sebaliknya dengan siswa yang memiliki kemampuan menggunakan alat ukur rendah dan kemampuan verbal rendah mereka terkendala dalam proses pembelajaran baik pembelajaran dengan menggunakan metode eksperimen maupun dengan metode POE, karena kedua metode tersebut mensyaratkan adanya kemampuan menggunakan alat ukur tinggi untuk metode eksperimen dan kemampuan verbal tinggi untuk metode POE, sehingga prestasi kognitif siswa yang memiliki kemampuan menggunakan alat ukur rendah dan kemampuan verbal rendah lebih rendah dibandingkan dengan siswa yang memiliki kemampuan menggunakan alat ukur rendah dan kemampuan verbal tinggi.

\section{f. Hipotesis Ketujuh}

Berdasarkan hasil keputusan uji maka Ho diterima pada prestasi kognitif dan afektif. Hal ini dapat disimpulkan bahwa tidak terdapat interaksi pembelajaran kontekstual menggunakan metode POE, eksperimen, kemampuan menggunakan alat ukur, kemampuan verbal terhadap prestasi kognitif dan afektif.

Dari data dapat disimpulkan bahwa siswa yang memiliki kemampuan menggunakan alat 
ukur dan kemampuan verbal menggunakan metode POE rata-rata prestasi lebih baik jika dibandingkan dengan metode eksperimen. Sehingga pengaruh metode lebih dominan dalam menentukan prestasi kognitif siswa. Hal berarti faktor eksternal siswa lebih berpengaruh terhadap prestasi belajar siswa. Hal ini sejalan dengan pendapat Muhibbin Syah (1995:139) yang menyatakan bahwa hal-hal yang mempengaruhi belajar siswa adalah salah satunya faktor metode pembelajaran yang digunakan guru. Hal ini berdampak terhadap tidak adanya interaksi antara metode, kemampuan menggunakan alat ukur, dan kemampuan verbal siswa. Siswa yang menggunakan metode POE mampu meningkatkan keaktifan siswa secara individual, sehingga berdampak terhadap proses penyimpanan dan pengambilan informasi secara optimal. Siswa yang memiliki kemampuan verbal, ia mampu mengungkapkan ide-ide, gagasan dan pendapatnya baik dalam bahasa tulisan maupun lisan sehingga berdampak positif terhadap prestasi belajar secara merata.

Untuk siswa yang mendapat metode eksperimen kurang mampu mendorong siswa untuk aktif secara menyeluruh atau hanya sebagian siswa yang benar-benar aktif dalam proses pembelajaran karena terwakili oleh kelompok-kelompok. Sehingga baik kemampuan menggunakan alat ukur ataupun kemampuan verbal siswa juga hanya sebagian yang dapat tergali secara optimal dampaknya kurang meratanya hasil nilai prestasi kognitif dengan nilai yang baik.

\section{Kesimpulan dan Rekomendasi}

Adapun kesimpulan penelitian ini antara lain sebagai berikut: 1) pembelajaran kontekstual melalui metode POE dan eksperimen berpengaruh secara signifikan terhadap prestasi belajar kognitif dan afektif. Hasilnya rata-rata prestasi kognitif metode POE lebih baik daripada daripada metode eksperimen. 2) kemampuan menggunakan alat ukur siswa tidak berpengaruh secara signifikan terhadap prestasi belajar dalam ranah kognitif maupun ranah afektif; 3) kemampuan verbal berpengaruh secara sigifikan terhadap prestasi kognitif dan afektif belajar siswa. Pembelajaran kontekstual mendorong siswa untuk aktif membangun pengetahuan secara mandiri baik sikap, bahasa verbal lisan ataupun tulisan; 4) tidak ada interaksi yang signifikan antara metode pembelajaran dengan kemampuan menggunakan alat ukur terhadap prestasi belajar kognitif dan afektif siswa. Tinjauan menggunakan alat ukur tinggi dan rendah, metode POE memiliki hasil rata-rata prestasi kognitif dan afektif lebih baik daripada metode eksperimen. 5) tidak ada interaksi yang signifikan antara metode pembelajaran dengan kemampuan verbal terhadap prestasi belajar kognitif dan afektif siswa. Ditinjau dalam ranah afektif rata-rata prestasi belajar kemampuan verbal lebih baik menggunakan metode POE dari pada eksperimen; 6) tidak ada interaksi yang signifikan antara kemampuan menggunakan alat ukur dengan kemampuan verbal terhadap prestasi belajar kognitif dan afektif siswa. Hubungan kemampuan menggunakan alat ukur terhadap prestasi belajar kognitif maupun afektif merupakan pengaruh yang independen dan tidak berhubungan dengan kemampuan verbal; 7) tidak ada interaksi yang signifikan antara metode pembelajaran, kemampuan menggunakan alat ukur, dan kemampuan verbal terhadap prestasi kognitif dan afektif siswa. Metode pembelajaran memberikan dampak yang sama terhadap dua variabel yang bersamaan dimiliki siswa yaitu kemampuan menggunakan alat ukur dan kemampuan verbal. Rekomendasi bagi peneliti lain yang disampaikan dalam tulisan ini adalah; (1). pembelajaran Fisika menggunakan pendekatan kontekstual melalui melalui metode POE dan eksperimen layak dijadikan alternatif dalam mengembangkan prestasi belajar siswa di kelas; (2). faktor kemampuan menggunakan alat ukur dan kemampuan verbal siswa hendaknya menjadi faktor yang patut dipertimbangkan dalam merancang proses pembelajaran di kelas.

\section{Daftar Pustaka}

Daimul Khasanah. (2010). Pembelajaran Fisika Berbasis Masalah dengan Menggunakan Metode Eksperimen dan Demontrasi ditinjau dari Kemampuan Menggunakan Alat Ukur dan Sikap Ilmiah Siswa. Tesis. Surakarta: Pascasarjana Universitas Sebelas Maret.

Depdiknas. (2004). Garis-garis Besar Program Pembelajaran dan Penilaian Pada Sistem Semester tentang Satuan Pendidikan SMP. Jakarta: Depdiknas. 
JURNAL INKUIRI

ISSN: 2252-7893, Vol 2, No 32013 (hal 216-227)

http://jurnal.fkip.uns.ac.id/index.php/sains

Dimas Candra. (2007). Prestasi Belajar Siswa ditinjau dari Kemampuan Verbal, Kemampuan Penalaran, dan Kemampuan Awal. Tesis. Surakarta: Pascasarjana Universitas Sebelas Maret.

David F. Treagust. (2007). An Investigation of The Classroom Use Of Prediction-ObservationExplanation Computer Tasks Designed to Elicit and Promote Discussion of Students' Conceptions of Force and Motion. Curtin University of Technology, Perth, Australia.

Hakan Özdemir, dkk. (2011). Effect Of Laboratory Activities Designed Based On PredictionObservation - Explanation (POE) Strategy On Pre-Service Science Teachers' Understanding Of Acid-Base Subject. dalam Wertern Anatolia Joernal Educational Science.

Hawkins et al. (2007). The jigsaw cabas school: protocols for Increasing appropriate behaviour and evoking Verbal capabilities. European Journal Of Behavior Analysis. Vol 8: pp. 203 -220.

Isjoni. (2007). Cooperative Learning. Bandung: Alfabeta.

Muhibbin Syah. (1995). Psikologi Pendidikan dengan Pendekatan Baru. Bandung: PT. Remaja Rosdakarya.

Mulyasa. (2006). Kurikulum Tingkat Satuan Pendidikan Sebuah Panduan Praktis. Bandung: PT. Remaja Rosdakarya.

Ratna Wilis Dahar. (1989). Teori-Teori Belajar. Jakarta: Erlangga.

Riyanto, Yatim. (2010). Paradigma Baru Pembelajaran. Jakarta: Prenada Media Group.

Sagala, Syaiful. (2011). Konsep Dan Makna Pembelajaran Untuk Membantu Memecahkan Problematika Belajar Dan Mengajar. Bandung. Alfabeta

Slameto. (2010). Belajar dan Faktor-Faktor yang Mempengaruhinya. Jakarta: Rineka Cipta. 